\title{
ECONOMIC EFFICIENCY OF INVESTMENTS INTO PERSONNEL DEVELOPMENT OF ENTERPRISES
}

\author{
Olena Kakhovska' \\ Prydniprovska State Academy of the Civil Engineering and Architecture, Ukraine \\ Tetiana Lositska² \\ Kyiv National University of Trade and Economics, Ukraine \\ Katerina Kolesnikova ${ }^{3}$ \\ Odessa Institute of Trade and Economics \\ of Kyiv National University of Trade and Economics, Ukraine
}

\begin{abstract}
The purpose of the article is the research of further improvement of investment process into personnel of the enterprises, using modern methods and tools, which are put into practice, for an increase in resulting economic effects of enterprise's activity. A key element in the functioning of companies is a balanced management system, so improving the effectiveness of investing in human capital should be considered by management as a priority. Therefore, it is important to improve the process of investing in personnel, using modern methods and tools that improve the efficiency of the company. Results. The structure of human capital is disclosed, which can be represented as a set of such components as health; competence; technical and special skills, which include the costs of continuing education, remuneration, other benefits and compensation. Problems that restrain investment of investments in personnel and tasks of personnel development policies are highlighted, the main one of which is maximizing the return on investment in employees. Practical implications. A motivating factor is an investment in planning and career motivation, which allows achieving a balance between the interests of the enterprise and the employee on the basis of principles: scientific, fairness, observance of labour legislation, efficiency, consistency. The definition of the economic efficiency of staff development in general form consists of three consecutive stages: the definition of the cost structure and their valuation; the definition of the structure of results and their valuation; comparison of the calculated values of costs and results reduced to one point in time. Value/originality. Management of investments aimed at the development of human capital will increase not only the effectiveness of the realization of human potential but also the efficiency of the use of all tangible and intangible assets of the enterprise.
\end{abstract}

Key words: investments in personnel development, investment efficiency, evaluation of investment efficiency in personnel, social aspect of investing in company personnel.

JEL Classification: D25, J24, M12, M53

\section{Introduction}

Level of economic development of any state depends on a large number of factors and components, among which an important place is taken by the level of functioning efficiency of the industrial companies as one of the main components in the state economic system. This efficiency is reached due to the creation of the balanced production management system on the basis of simultaneous and rational management of three types of the company capital: fixed capital, working and human capital. The last researches of domestic and foreign authors about the efficiency of investment into a human capital demonstrate that more significant and longer effect brings direct investments in forming and personnel development of the companies, instead, of the simple use of the fixed or working capital.

\footnotetext{
Corresponding author:

${ }^{1}$ Department of Accounting, Economics and Human Resources Management of Enterprise,

Prydniprovska State Academy of the Civil Engineering and Architecture.

E-mail: elena.kakhovskaya@gmail.com

${ }^{2}$ Scientific Research Department, Kyiv National University of Trade and Economics.

E-mail: ndch TL@knteu.kiev.ua

${ }^{3}$ Department of Applied Economics, Odessa Institute of Trade and Economics of Kyiv National University of Trade and Economics.

E-mail: ekolesnikova.od@gmail.com
} 


\section{Analysis of recent research and publications}

Problems of investment into a companies' human capital are very relevant for their effective work as personnel structure, its knowledge, abilities and professionalism become high-valuable assets of the enterprises, which at competent management are transformed to the capital bringing the increasing income to the owner of the business. Unlike costs for the workforce in the Ukrainian legal acts, as well as in the international regulating documents according to the work's statistics, there is no accurate and unambiguous determination of essence of investments into personnel, as in a human capital of any enterprise. Scientists of the different countries worldwide are engaged in the solution of this problem. The American economists McConnell and Brue (2013) define the essence of investments into personnel as certain actions and the related costs, which improve skills, capabilities, and labour productivity of workers and will be repeatedly compensated by the increasing income in the future. According to the authors, it can serve as the predominating incentive for such investments.

All human capital investments McConnell and Brue (2013, p. 484) divide into the following groups: expenses for education (include general and special, formal and informal preparation on a workplace); expenses on healthcare (expenses on prevention of diseases, medical attendance, dietary food, improvement of housing conditions); expenses on mobility thanks to which workers migrate from places with rather a low production to places with rather high.

According to one of the founders of the basic model theory of the intellectual capital $\mathrm{H}$. Becker, investments into the human capital, except offered by McConnell and Brue, still have to contain costs of children's education and also information search about the prices, income, and salary. This scientist for the first time carried out calculation of economic education efficiency by calculation of return from investments in the human capital. This efficiency is $12-14 \%$ of annual profit. H. Becker's (2003, p. 66) contribution to the development of a branch of knowledge under the name "Human Capital" still considered the main scientific work in this area.

Jac Fitz-enz (2006, p. 66), in turn, emphasized that investments into development of employees are costs of all educational and qualification actions of the enterprise and the program for development of personnel.

I.M. Novak (2006, p. 84-85) approaches determination of essence of investments into personnel at the corporate level based on "total costs of the employer on the reproduction of workforce power" of which "qualitatively new human capital with the high level of qualification, health and working capacity" is result.

Many researchers consider human capital investments as the instrument of influence and stimulation of reproduction. V.P. Antonyuk (2007) considers that human capital investments are "the costs performed for the purpose to increase in productive employee abilities and future income." O.M. Bilyk (2004, p. 382) connects increases in cost efficiency from investment into personnel with the subsequent natural macroeconomic growth and defines investments into an intellectual capital as "production costs of specific goods (certain means of production - knowledge, qualification, etc.), which are directed to a gain of opportunities and, as a result, the worker's earnings (the total revenues of the country)."

The interrelation between the efficiency of investment into a human capital and macroeconomic growth found the reflection in works of O.A. Grishnova (2001, p. 18) and S.O. Tsimbalyuk (2006, p. 104). Both authors consider that such attachments "bring quite considerable in volume, long in time, and integral in character economic and social effect."

A similar approach to the determination of investment's efficiency into personnel is noted also in work of such scientists as M. Bublik, V. Koval, V. Redkva (2017, p. 236).

Such differentiation of investment orientation promotes identification of the most effective directions of investments based on the analysis of the level of return, labour productivity, and dynamics of indicators' change of intellectual potential and physical health of employees. In the same manner increase in the level of motivation and interest in good results of the production process is a positive tendency of forming, development and reproduction of a human capital.

Despite numerous researches concerning the concept "investment into personnel" and efficiency assessment of such investment, such researches have no system complex character, in addition, have no connected investments into personnel with the decision to invest and also to decide social problems of personnel.

The purpose of the article is the research of further improvement of investment process into personnel of the enterprises, using modern methods and tools, which are put into practice, for an increase in resulting economic effects of enterprise's activity.

\section{Fundamentals of the formation and functioning of the policy of investing in personnel}

Now, human resource management becomes one of the most significant strategic management functions. It is connected with the fact that in the economy based on knowledge, a workforce is the carrier of the labour and intellectual potential capable of providing competitive force and realizing the profitability potential of the economic entity in the achievement of long-term prospects by it. The practice of the developed countries showed that the considerable competitiveness of the companies is guaranteed by no means not so much at 
the expense of natural resources and the progressive equipment, how many for the account results of rapid formation of the human capital. Human potential, managers' ability to competently put and execute the purposes, and also effective use of resources become major factors of the successful existence of the enterprise.

In these conditions, achievement of strategic objectives of human resource management is impossible without the implementation of investments into personnel assuming costs of development and realization of labour potential and formation of the human capital as a non-material asset of the economic entity capable of bringing income to both the worker and the employer. The concept "investments" is, first of all, the process of an investment in the enterprise's assets for the purpose of receiving investment income.

Investment process always assumes receiving income, which has to be predicted, planned, and calculated, and investment decisions are agreed with the strategic objectives of the company. Therefore, it is necessary to plan, consider, analyse, and control not only the expenses connected with compensation for the use of labour but also expenses, which are carried out for the purpose of development and realization of labour potential and formation of the human capital. There are sets of such components as health; the general skills connected with basic preparation, ability of information search and its use during the solution of problems, natural abilities and education level; the technical and special skills connected with engineering procedures, including physical capacities and also the analytical skills leading to improvement existing or to the creation of new equipment and technologies, which can present the structure of the human capital.

Moreover, if employees pay the general skills independently or they are financed by the state, then other components of the human capital demand investments from the enterprises. Therefore, investing in labour protection, the company will help to keep the health of employees at the necessary level, to cut expenses on payment of sick leave, and to reduce losses because of the employees' absence in a workplace. All these actions can be considered income from investments in healthcare.

Now the mortality rate in Ukraine among other countries of Europe also makes the highest 1455 people on 100 thousand of the population. For comparison, the minimum level of mortality is in Switzerland 467,2 persons. Western Europe, in general, has by 1,5 times lower mortality rate, than Central Europe, and in the Balkan countries, except Greece, and the Baltic countries the mortality rate represents nearly 1 thousand on 1000 thousand persons. Maintaining health and efficiency of personnel at the enterprises is promoted by strengthening of labour protection and improvement of working conditions through the improvement of the organization and service of workplaces, introductions of ergonomic actions and so forth. It provides the need of accurate observance of the legislation requirements of for the sphere of labour protection, investigation and accident prevention on production and occupational illnesses, ensuring receiving by workers all the provided legislation and collective agreements of privileges and compensations for working conditions (Info-light, 2017).

Investments into technical and special components are connected as with the search of the necessary employees meeting certain requirements so with the development of their potential and preservation of these personnel in the company. Carry costs for professional development, the worthy compensation capable of holding the employee at the enterprise, other privileges and compensations to such investments. At the same time, an important point is the understanding of the dependence of the number of personnel, valuable to the enterprise, on the level of investments in it. It is possible to carry to such investments: costs of the search of competent experts, the salary, privileges, and other payments, funds allocated for professional development and the level of special and technical knowledge and skills, and also the funds allocated for health protection and insurance. The competitive salary, privileges and other payments increase the probability that all investments directed to the development of special and technical skills reduce the risk of the departure of the employee from the enterprise. Besides, they promote an increase in productivity as are the important motivating factor.

Investments into planning and motivation of career allow reaching balance between the interests of the enterprise and the worker as the consecutive advance of the employee on a number of positions promotes the realization of concrete goals of the enterprise. Thus leads also to the development of the intellectual potential of the worker and definition of a position, at which he could work with the bigger creative return.

However, only the expenses of the enterprises connected with compensation are carried out according to the existing current legislation. And investments in personnel (professional education; motivation for development; directly development of personnel; health protection), are performed with the presence at the enterprise of free financial resources and the sufficient level of competence of the enterprises' chiefs, allowing to estimate economic feasibility of certain costs of personnel for the purpose of its development for receiving additional, higher profit. At the same time, the policy of investment into personnel has to be characterized by the systematic approach and its complexity, which, in its turn, relies on such principles as a scientific character, justice, observance of the labour law, efficiency, the sequence, methodicalness.

In the conditions of maximizing profit, the owner of the company interests whether investments in the human capital are expedient as they affect resulting economic effects of activity of the company how 
developed principles of work on the development of personnel promote achievement of strategic objectives. Heads have to perceive the employees as a potential source, but faith in employees as in a financial leverage meets seldom, and many managers consider these efforts not investment, but the next expenses.

It is possible to allocate the following problems that constrain an investment of expenses into personnel: any invest interest of employers in personnel in connection with an indistinct understanding of efficiency of these investments; insufficiency of financial resources for ensuring investments into the human capital; insufficient level of encouragement of professional workers' development; uncertainty of the employer concerning loyalty of workers who undergo study as workers who improved skills can pass to other enterprise that will lead to loss of finance; lack of the universal method of investments' efficiency assessment into personnel; insufficient motivation of workers to increase in the professional level; misunderstanding by employers of cause and effect relationship between investments into personnel and efficiency of the enterprise's activity; complexity of expenses' definition, which need to be performed to investments into personnel; neglect difference in return from investments into different categories of personnel (Momcheva, 2013); the long period of return on investment in personnel, which, by estimates of researchers, only in education make 10-20 years, and on average -16 years (Novak, 2006).

Despite the big costs connected with the training of skilled workers and maintenance of their qualification level, the modern organizations nevertheless consider costs of development of personnel as investments, which respectively have to bring a return in the form of an increase in efficiency of the enterprise's activity.

Statistically, the most part of investments in the study of personnel is made by the companies, which are engaged in finance, insurance, the real estate, high technologies and transport services. And, mostly, a smaller part of investments is made by the companies in the field of production, healthcare, agriculture, construction and development of fields. At the same time, in the companies from officially fixed by the strategy of human resource management revenue counting on one employee is nearly 3 times higher, and return from investments into personnel is $70 \%$ more, than at the companies, which have no such fixed strategy (Risin, 2009).

One of the main objectives of the development policy of personnel is maximizing return from capital investments in employees. Such economic justification of the offered policy of development can be based on the analysis of the existing policy, assessment of the efficiency of the held events, the introduction of necessary changes. Thus, calculation of economic efficiency of separate elements of personnel development - planning of career, vocational education of personnel, and preparation of a personnel pool will allow realizing the system approach defining the influence of the system of personnel development on all company in general.

\section{Stages of the process of assessing the effectiveness of investment in personnel development}

Determination of the economic efficiency of personnel development in a general view consists of three consecutive stages:

1) determination of expenses structure and their cost assessment;

2) determination of results structure and their cost assessment;

3) comparison of the estimated sizes of expenses and results brought to one timepoint.

It is known that the production efficiency only for $30-35 \%$ depends on investments, the others - on the skill level of workers and experts. It is possible to draw conclusions from such figures on the importance of vocational training on production: in the countries of the European Union, the frequency of professional development of workers representsabout 5 years, inJapanfrom 1 to 1,5 years, in Ukraine professional development is carried out each 12 years (Gemma, 2013).

Revenue, profit, prime cost, products, development on one worker, losses of working hours on one worker, the average salary on one worker, etc. can act as indicators of the activity results in the organization reflecting the influence of personnel development.

The main attention of modern researchers and analysts is concentrated on the assessment of the efficiency of vocational education. However, the existing techniques can be used for the assessment of development's efficiency in general, as training is a key element of the system and the main form of development of personnel.

The most popular is the four-level model of assessment of learning efficiency and methodology of calculation of return on investment into training (Return On Investment (ROI)), which were developed by the famous expert in the field of human resource management Jack Phillips in the early nineties. The essence of this technique comes down to the creation of a relationship of cause and effect between the provided training and result of the activity of the trained personnel.

Stages of the process of efficiency's assessment of investments into the personnel development (based on Jack Phillips's technique):

I. Planning. The plan of investments' assessment into the personnel development, which contains:

1. The description of indicators, which dynamics will characterize results of the provided training. These indicators have to be the objective and economic effect of their change (growth in incomes, cost cutting) can be estimated. 
2. The methodology of data collection (questioning, observations of personnel, analysis of the administrative reporting, etc.).

3. Sources of data collection (reporting of the enterprise, participants in training, heads, working groups, etc.).

4. Evaluating terms.

5. List of the persons responsible for collecting and data processing necessary for assessment.

II. Data collection is made according to the methodology defined at the first stage during, in time and after training for objective assessment of the dynamics of the chosen indicators.

III. Identification of effect of the provided training. For an exception of the influence of the external factors that are not connected with the provided training the following approaches are used:

- trend analysis of the previous periods. The tendency of indicator's change before carrying out training is defined. The difference between a trend and the actual result is attributed to training influence;

- expert assessment of the influence of the gained knowledge on indicators' dynamics. Managers of the company, detached onlookers or other training's participants can act as experts.

IV. Transformation of the obtained data to a money equivalent. The indicators characterizing productivity, quality, and time expenditure are transformed.

When calculating total costs of training, the salary of employees, administrative expenses, etc. are considered not only costs of development of the training's program, such as manipulative materials, a fee of experts and rent.

Calculation of value of an indicator "return on investment" (ROI) is made on a standard formula:

$R O I=(G I-E) / E$,

where GI - Gain on income(profit); E - expenses for education(training).

There are four main aspects, which should be considered for the calculation of the ROI of investments into personnel: productivity; absenteeism (absence from the workplace for various reasons); turn; adaptation speed. Each of indicators plays an important role in the assessment of investments into personnel, but it is necessary to focus on something one as too many factors influence a resulting effect - profit. So, for example, results of the research conducted by Robert Zemsky et al. (2002) demonstrate that increase in education level by $10 \%$ productivity grows by $8.6 \%$, and the same growth of fixed assets increases productivity only by $3.4 \%$. Thus, the profitability of investments in the human capital is almost three times higher, than investments in cars and the equipment.

Not always, it is possible to isolate indicators, which are not subject to external factors' influence. In such cases, it is necessary to confirm the received value of an ROI's indicator, having analysed the effect of the provided training in three directions: "reaction of participants of a seminar", "knowledge" and "behaviour". If in these directions good results are received, it is possible to claim that distortion of assessment of ROI is insignificant or is absent.

Introduction of ROI assessment's system in training significantly simplifies life to specialists in personnel and improves their mutual understanding with top management as the report on training can be presented in the form of tables, from which it is accurately visible how many employees were trained, what expenses, what gain of business indicators. In addition, to financial service with its help, it is easy for top managers to estimate return from the provided training.

JacFitz-enz (2006) as a key indicator for determination of investments' efficiency into personnel suggests using return on investment coefficient in the human capital (HCROI). It is defined as a ratio of the profit got after a deduction of all expenses on labour (except for the salary and privileges) and the size of expenses on labour (the salary and privileges).

Voronkova, Belichenko, \& Popov (2006) adds to the key indicators of investments' efficiency of: productivity indicators; speed of passing of the business's procedure, engineering procedure; expenses and any results when performing special programs and initiatives; skills of workers, loyalty, moral atmosphere in collective; ability of personnel to study, transparency of the procedure of investment.

Hamblin and Kirkpatrick's method does not allow how much the company needs funds for training personnel in order to reach the correctly set business goals, and Tobin \& Stephen S. Golub (1998) proposed to calculate the indicator of intellectual capital as a whole as the ratio of the market value of the asset to replacement cost.

\section{Transformation of investment activity and investment portfolios of companies in the direction of increasing expenditures on human capital}

Investments into the human capital have to be considered on an equal basis with investments into development and maintenance of business. Motives of investment into the human capital have to be defined not only economic, but cultural, psychological, and social factors.

For the achievement of economic success, business firms have to be socially oriented that forces them to change the investment strategy, including the structure of the investment portfolios in social projects (Koval, Prymush, \& Popova, 2017).

Alreadybig and average, and sometimes small enterprises are estimated from a position of the relationship between workers and consumers, between workers and the management (owners) and also estimate according to their contribution to society and its development. Thus, 
the enterprises from "business" of the enterprises become the "social" enterprises, which in the mission combine a gain of income and support of interaction with the external environment, investing and actively directing economic trends that form the world. The emergence of this kind of the enterprise is promoted by the following factors (Kaji, Edelman, \& Khan, et al., 2018):

- the growth of individuals in business: more attention is paid to the quality of work and influence of work's results on a society where the enterprise functions, thanks to globalization and fast communication, which gives an opportunity hyper-quickly to communicate and express the opinion, influencing social changes globally and in real life;

- the business itself is able to fill a so-called vacuum in society: based on world poll, it was revealed that business embodies trust of the population for $54 \%$ against $43 \%$ of trust to the government. People wait from business for decisions in healthcare, the safety of a cyberspace, the help in making the world fairer, etc.;

- technical progress has a bilateral impact on society: on the one hand - serious opportunities to reach stability and growth, on the other hand - training of cars, artificial intelligence, the performance of work instead of the person. All this needs mastering from the person new knowledge and skills and consequently, needs investments into personnel.

The enterprise has to be the active participant of social life and social projects today, consider a certain trend in labour market development. Yes, more and more workers pass into a work freelance segment, rendering the services as the entrepreneur. The enterprises have to consider such opportunities of cooperation already now, understanding all its pluses and shortcomings. Now for the successful person, his development is on the first place and if the enterprise considers and encourages the development of the person in the company, the level of efficiency of this person is much higher, than those who act as a part of collective.

The main criterion of success of the company success of each worker as parts of this enterprise appears. The last becomes impossible without investment into the continuous development of workers. Besides, the farsighted organizations see a certain potential and an opportunity for an increase in life and professional experience with life expectancy growth. Usually, it needs innovative methods and policy of maintenance due to investments of a longer career, development of new career models. Twenty percent of defendants of a research confirmed cooperation with workers of advanced age. This factor of durability allows the companies to solve an urgent social problem and to get advantages from employees devoted to the company with wide professional experience.

Importance of the embodiment of new approaches to the development of personnel due to investments in personnel is confirmed by data of the international poll on regions of the whole world (Table 1). The tendency to increase in life expectancy, in turn, increases the number of 55 years working further on. In Figure 1, the level of interest in workers of advanced age is displayed.

In spite of the fact, that the general statistics show not great interest to workers of advanced years, but, according to the same statistics (Kaji, Edelman, \& Khan, et al., 2018), during the period from 1996 to 2014, about $68 \%$ of the senior workers (at the age of 55-64 years) opened the enterprises and began new business in comparison with $32 \%$ of young businessmen (at the age of 20-34 years). Besides, workers of advanced years, which worked in IT, study several times quicker new mobile programming, work with artificial intelligence, and other modern technologies. They should not spend 5-8 years on the study if to speak about youth.

Such an approach needs creation of new programs of personnel's investments for people of advanced years quicker to adapt them to the enterprise's activity. Global tendencies indicate the general aging of the population, and most likely the enterprises, which will ignore this fact, will not be able to compete with those companies, which considered this tendency further. Creation of such an environment in the company, which will maximize the advantages of workers of advanced years, is necessary. However, for this purpose it is necessary to reconstruct radically approaches to improvement of knowledge, skills,

Table 1

Value of factors of personnel's development depending on the region

\begin{tabular}{|c|c|c|c|c|c|c|c|c|c|c|}
\hline \multirow[b]{2}{*}{ Factors } & \multirow[t]{2}{*}{ Global } & \multicolumn{2}{|c|}{ Americas } & \multicolumn{5}{|c|}{ Europe, Middle East and Africa } & \multicolumn{2}{|c|}{ Asia Pacific } \\
\hline & & $\begin{array}{c}\text { Latin \& } \\
\text { South } \\
\text { America }\end{array}$ & $\begin{array}{c}\text { North } \\
\text { America }\end{array}$ & Africa & \begin{tabular}{|c|} 
Central \& \\
Eastern \\
Europe
\end{tabular} & $\begin{array}{c}\text { Middle } \\
\text { East }\end{array}$ & $\begin{array}{c}\text { Nordic } \\
\text { countries }\end{array}$ & $\begin{array}{l}\text { Western } \\
\text { Europe }\end{array}$ & Asia & Oceania \\
\hline From careers to experiences & $84.1 \%$ & $87.2 \%$ & $80.6 \%$ & $84.7 \%$ & $80.3 \%$ & $81.3 \%$ & $81.4 \%$ & $79.8 \%$ & $91.6 \%$ & $87.3 \%$ \\
\hline Well-being & $84.0 \%$ & $88.2 \%$ & $78.9 \%$ & $88.0 \%$ & $75.1 \%$ & $84.8 \%$ & $83.3 \%$ & $80.1 \%$ & $91.6 \%$ & $86.6 \%$ \\
\hline The hyper-connected workplace & $82.1 \%$ & $85.5 \%$ & $84.6 \%$ & $85.0 \%$ & $72.8 \%$ & $79.9 \%$ & $84.3 \%$ & $78.9 \%$ & $83.6 \%$ & $89.0 \%$ \\
\hline New rewards & $77.4 \%$ & $85.3 \%$ & $71.1 \%$ & $85.6 \%$ & $74.8 \%$ & $85.0 \%$ & $58.8 \%$ & $69.8 \%$ & $87.5 \%$ & $65.6 \%$ \\
\hline Citizenship and social impact & $76.7 \%$ & $81.0 \%$ & $76.1 \%$ & $86.8 \%$ & $63.6 \%$ & $76.6 \%$ & $67.8 \%$ & $72.0 \%$ & $83.0 \%$ & $82.8 \%$ \\
\hline AI, robotics, and automation & $72.4 \%$ & $70.4 \%$ & $64.5 \%$ & $70.7 \%$ & $67.0 \%$ & $74.5 \%$ & $83.0 \%$ & $69.2 \%$ & $84.1 \%$ & $73.2 \%$ \\
\hline The longevity dividend & $69.1 \%$ & $74.8 \%$ & $59.7 \%$ & $73.2 \%$ & $58.1 \%$ & $70.5 \%$ & $63.8 \%$ & $69.2 \%$ & $76.5 \%$ & $66.7 \%$ \\
\hline
\end{tabular}

Source: formed on the basis (Kaji, Edelman, \& Khan, et al., 2018) 


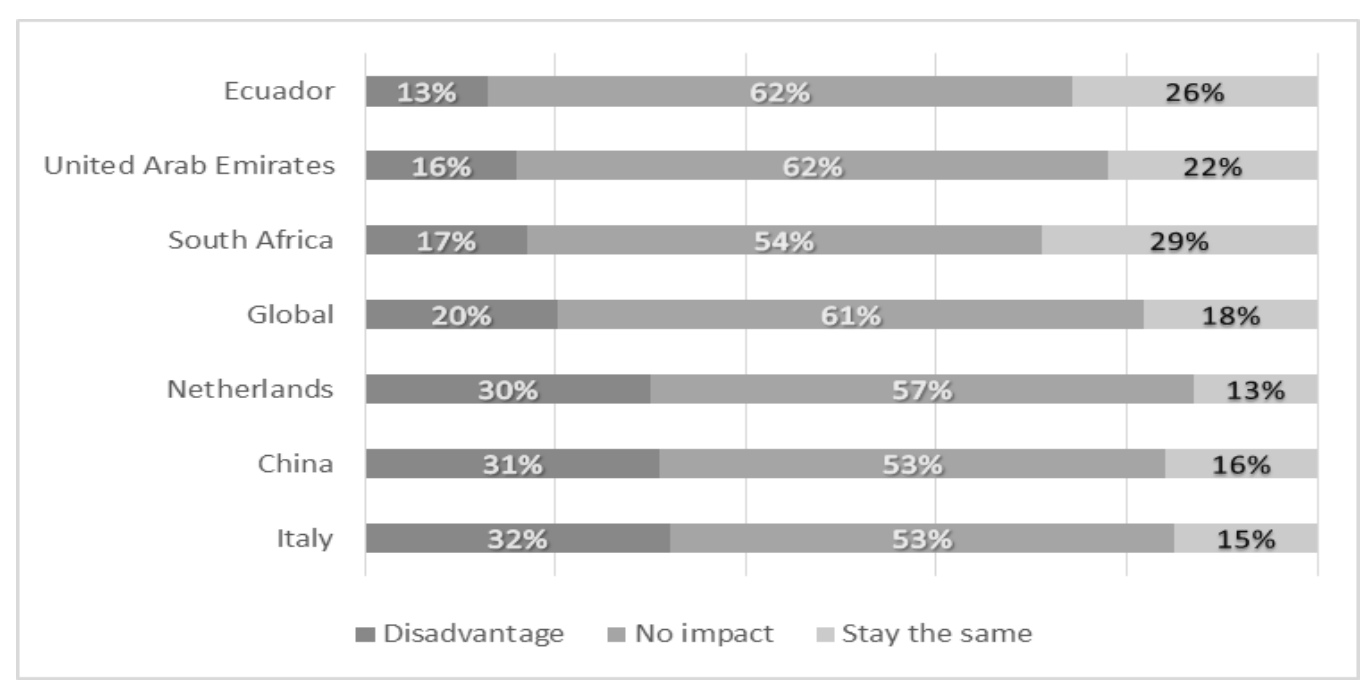

Figure 1. Organizational attitude for the older workers (over 55)

Source: formed on the basis (Kaji, Edelman, \& Khan, et al., 2018)

and competencies of workers, considering 35-40 years of fruitful work, instead of 20-25 years as it paid off earlier. Thus, after 55 years, employees will own the same knowledge, skills, as well as youth, but they still will have an experience, which they will be able already to give to the younger generation of workers.

Another trend is a tendency to change in the employees' approach to work. Recent researches (Kaji, Edelman \& Khan, et al., 2018) showed that more than $75 \%$ of youth (aged from 20 up to 35 years) plan to open own business, it is more than $70 \%$ of this $25 \%$ which remained will work as freelancers and only $12 \%$ of this $25 \%$ assume full work at the enterprise. The similar tendency has to be considered by experts in human resource management, to include such workers in programs of professional development, obtaining new skills and knowledge at the level with permanent members of staff.

\section{Conclusions and further researches directions}

In the conditions of economic instability, a lack of resources and investments, many Ukrainian companies begin to save on everything and, first of all, on personnel: cut down salaries, social payments, worsen working conditions. However, it is worth remembering that income from investments into the human capital gets not only to the carrier of the human capital but firstly to the organization in which it is implemented, further to the region and the country in general.

Strategic management of the investments aimed to the development of the human capital will allow increasing not only efficiency of realization of human potential, but also the efficiency of use of all material and intangible assets of the company. The human errors arise because of low qualification that can lead to big losses and do harm to production and health of the personnel. All above-mentioned causes the enhanced attention to the person as to a major factor of production especially as in modern conditions to achieve a gain in productivity is possible only thanks to the intellectual potential of personnel. Therefore, economic stability and competitiveness of the enterprise, first of all, depend on effective investments into the human capital at the optimum control of risks in this sphere.

New tendencies indicate in personnel's development and views of a working environment indicate need of investments' uses not only into increase in professional knowledge of already existing workers: considerable investments reorganization and adaptation of new models, programs and the systems of integration of the existing world trends in the workforce market demands, which are objective and have to be considered. Further ignoring of these trends will lead to problems of braking of development of the companies, and as a result - spheres and branches of national economy. An integrated approach to the assessment of investment's efficiency into the personnel development provides adoption of reasonable decisions in the sphere of the human capital's management of the companies.

The fullest use of all opportunities and directions of investment into personnel at the level of the company will allow providing: the gain in productivity of work, which leads to increase in volume of made production and services and, as a result, to increase in profit of the company; increase in competitiveness of products and company services thanks to improvement of their quality and optimization of costs of their production; reduction and elimination of unproductive expenses and losses of time during production; reduction of turnover of staff and prevention of staff shortage on the most important production positions; optimization of number of staff of the enterprise; improvement of qualitative characteristics of personnel of the company; increase in motivation to work at workers. 


\section{References:}

McConnell C.R. \& Brue S.L. (2013). Economics: Principles, problems, and policies. Boston McGraw-Hill Irwin.

Becker G. (2003). Human behaviour: economic approach. The chosen works according to the economic theory. M.: SU HSE. (in Russian)

Fitz-enz Jac (2006). Profitability of investments into personnel: measurement of economic value of personnel. V.I. Yarnykh (Ed.). (M.S. Menshikova, Yu.P. Leonova, Trans). M.: Vershina. (in Russian)

Novak I.M. (2006). Modern priorities of investment of the human capital in Ukraine. The Collection of scientific works of the Kharkiv national economic university, Management of development, 4, 83-86. (in Ukrainian)

Antonyuk V.P. (2007). Formation and use of the human capital in Ukraine: social and economic assessment and ensuring development: [monograph]. Donetsk: NAS Ukraine. Institute of industry's economy. (in Ukrainian)

Bilik O.M. (2004). Investments into the human capital: value and specifics. Social and economic aspects of industrial policy. Management of human resources: state, region, enterprise. V. 1, 380-386. (in Ukrainian)

Grishnova O.A. (2001). Human capital: formation in an education system and vocational training. Kyiv: S-ty "Znannya". (in Ukrainian)

Tsimbalyuk S.O. (2006). Preparation and professional development of personnel as direction of investment of means into the human capital. Collection of scientific works of the Kharkiv national economic university. Management of development, 4, 103-107. (in Ukrainian)

Info-light information and analysis center (2017). Retrieved from: http://infolight.org.ua/content/demografiyasumna-statistika (in Ukrainian)

Momcheva A.M. (2013). Investments into personnel as factor of increase in efficiency of activity of the organization. Efektivna ekonomika. Retrieved from: http://www.economy.nayka.com.ua/?op=1\&z=2400 (in Ukrainian)

Risin I.Ye. (2009). Investment in personnel as a factor of enterprise efficiency increasing. Upravlinnia personalom, 15, p. 37. Retrieved from: http://www.top-personal.ru/issue.html?2126 (in Ukrainian)

Gemma M.D. (2013). Problems of professional study development of personnel on production at the present stage of formation of Ukraine. Sotsyalno-trudovy vidnosyny ta praktyka, 2, 176-180. (in Ukrainian)

Zemsky R., Shaman S. \& Shapiro D. (2002). Higher Education as Competitive Enterprise: When Markets Matter. New Directions of Institutional research.

Voronkova V.G. (Ed.), Belichenko A.G. \& Popov O.M. (2006). Management of human resources: philosophical principles: education guidance. Kyiv: Professional. (in Ukrainian).

Tobin James \& Stephen S. Golub (1998). Money, Credit, and Capital. Irwin/McGraw-Hill. TOC.

Kaji J., Edelman K., Khan A., et al (Eds). (2018). The rise of the social enterprise 2018 Deloitte Global Human Capital Trends. Deloitte Development LLC (2018). Retrieved from: https://www2.deloitte.com

Bublyk M., Koval V. \& Redkva O. (2017). Analysis impact of the structural competition preconditions for ensuring economic security of the machine building complex. Marketing and Management of Innovations, Vol. 4, 229-240. DOI: $10.21272 / \mathrm{mmi}$.2017.4-20.

Koval V., Prymush Y. \& Popova V. (2017). The Influence of the Enterprise Life Cycle on the Efficiency of Investment. Baltic Journal of Economic Studies, Vol. 3, Is. 5, 183-187. DOI:10.30525/2256-0742/2017-3-5-183-187. 